\title{
The Relationship Between the Adequacy of Iron Tablet Supplementation and Hemoglobin Level in Pregnant Women
}

\author{
Afwandi Afwandi ${ }^{*}$, Sugito Sugito ${ }^{2}$, Nurliana Nurliana ${ }^{3}$, Rinidar Rinidar ${ }^{4}$, Teuku \\ Reza Ferasyi ${ }^{3}$ \\ ${ }^{1}$ Master graduate of Study Program of Veterinary Public Health, Universitas Syiah Kuala, Banda Aceh \\ ${ }^{2}$ Laboratory of Clinic, Faculty of Veterinary Medicine, Universitas Syiah Kuala, Banda Aceh \\ ${ }^{3}$ Laboratory of Veterinary Public Health, Faculty of Veterinary Medicine, Universitas Syiah Kuala, Banda Aceh \\ ${ }^{4}$ Laboratory of Pharmacology, Faculty of Veterinary Medicine, Universitas Syiah Kuala, Banda Aceh \\ *Corresponding author. Email: afwandi833@yahoo.com
}

\begin{abstract}
Anemia is problem commonly occurs in pregnant women. Pregnant women are said to be anemic if their hemoglobin levels are less than $11 \mathrm{~g} / \mathrm{dl}$. This condition occurs because of the insufficient intake of iron (Fe) to meet the increased need of the body during pregnancy and childbirth. The incidence of Fe deficiency related anemia in pregnant women in Indonesia ranges from 20-25\%. Therefore, pregnant women are advised to consume at least $90 \mathrm{Fe}$ tablets with a dose of 1 tablet per during 90 initial days of pregnancy. The tablet contains $200 \mathrm{mg}$ of ferrosus sulfate and $0.25 \mathrm{mg}$ of folic acid bound with lactose. The purpose of the research was to determine the relationship between the adequacies of Fe supplementations with the hemoglobin level of pregnant women in Johan Pahlawan District, West Aceh Regency. This quantitative study used a cross-sectional design involving 62 out 165 pregnant women in the second and third trimesters who were recorded at Johan Pahlawan and Suak Ribee Primary Health Centers, Johan Pahlawan Subdistrict. The subjects were recruited by a purposive sampling. The results showed that iron tablet supplementation was very significantly related $(\mathrm{p}<0.001)$ to hemoglobin level of pregnant women.
\end{abstract}

Keywords: Iron tablet, Fe, hemoglobin level, pregnant women

\section{INTRODUCTION}

Anemia is a health problem commonly occurs in pregnant women. The prevalence of anemia increases in pregnancy from trimester II to trimester III by 2 to 3 times [1]. A pregnant woman is said to be anemic if their hemoglobin $(\mathrm{Hb})$ level is lower than the normal limit, 11 $\mathrm{gr} / \mathrm{dl}[2,3]$. Anemia occurrs when the need of the body for iron $(\mathrm{Fe})$ is higher than its intake from diet, a situatin found in menstruation, pregnancy and childbirth [4]. The need for iron in the first trimester of pregancy is low $(0.8$ $\mathrm{mg} /$ day), and then increases markedly in the second and third trimesters of pregnancy $(6.3 \mathrm{mg} /$ day $)$. This relates to the progressive increase of blood volume from the $6^{\text {th }}$ to $8^{\text {th }}$ week of pregnancy, and reaches a peak in week 32-34 [5].

Increased plasma volume during pregnancy causes a dilution of blood cells [6] and decreases in hemoglobin level from $15 \mathrm{~g} / \mathrm{dl}$ to $12.5 \mathrm{~g} / \mathrm{dl}$, and in $6 \%$ of pregnant women it can reach below $11 \mathrm{~g} / \mathrm{dl}[6,7]$. Low $\mathrm{Hb}$ level in the late pregnancy is an abnormal condition usually associated with Fe deficiency. Therefore, it is necessary to increase iron intake in a pregnant woman to help restore of hemoglobin level [7].

The prevalence of anemia in pregnant women in Indonesia increases dramatically from $37.1 \%$ in 2013 [8] to $48.9 \%$ in 2018 [9]. Aceh is one of regions in Indonesia with high of anemic pregnant women (46\% in 2018) [9]. In the West Aceh regency alone, the prevalence of anemia in pregnant women reaches $30.7 \%$ in 2019 [10]. The primary health centres in Johan Pahlawan and Suak Ribee of Johan Pahlawan Subdistricts of West Aceh reported the case of anemia in pregnant women of $36.5 \%$ and $70.7 \%$, respectively [11]. In order to reduce the case Aceh has implemented a Fe-tablet supplementation program in pregnant women with a coverage of $73.6 \%$ in 2018 [12]. In 2019, pregnant women in West Aceh involved in Fetablet supplementation program are $66 \%$. With a coverage 
reaches $86 \%$ and $68 \%$ the primary health centres of Suak Ribee and Johan Pahlawan are the most active health cares involved the Fe-tablet provision in this regency [10].

The provision of $\mathrm{Fe}$ supplementation can reduce the incidence of anemia in pregnant women by $20-25 \%$ [7] Each Fe tablet contains $200 \mathrm{mg}$ of ferrosus sulfate and $0.25 \mathrm{mg}$ of folic acid bound to lactose. A pregnant women is advised to consume at least $90 \mathrm{Fe}$ tablets with a dose of 1 tablet per day for 90 consequtive days $[13,14]$. The supplementation of Fe tablet according to recommended dose accompanied with an adequate diet strongly relates with increased $\mathrm{Hb}$ level in pregnant women $[15,16]$.

This study was done to investigate the relationship between the adequacy of $\mathrm{Fe}$ supplementation and hemoglobin levels for pregnant women in Johan Pahlawan sub-district, West Aceh regency.

\section{MATERIALS AND METHODS}

This quantitative, cross sectional study was conducted at the Primary Health Centers of Johan Pahlawan and Suak Ribee, Johan Pahlawan Subdistrict, West Aceh from April to June 2020. Subjects were 62 out of 165 pregnant women in the second and third trimesters recorded at the health centres in February 2020 and voluntarily participated in the study after completing the informed consent. The subjects were purposively selected based on inclusion criteria as follow: pregnant women in the $2^{\text {nd }}$ and $3^{\text {rd }}$ trimesters of pregnancy without blood disorders. The sample size was determined based on the Slovin formula [17]. Data obtained were analyzed using univariate and bivariate chi-square analyses.

\section{RESULTS AND DISCUSSION}

\subsection{Adequacy of Iron Supplementation}

The profil of iron tablet consumption and $\mathrm{Hb}$ level of pregnant women in Johan Pahlawan Subdistrict are presented in the Table 1.

Table 1. Iron tablet consumption and hemoglobin level of pregnant women in Johan Pahlawan, West Aceh

\begin{tabular}{|l|c|}
\hline Variable & Number \\
\hline $\begin{array}{l}\text { Adequacy of Fe tablet supplements } \\
\text { Enough } \\
\text { Not enough }\end{array}$ & $26(41.9 \%)$ \\
\hline Total & $36(58.1 \%)$ \\
\hline Hemoglobin level & $62(100 \%)$ \\
Normal & $30(48.4 \%)$ \\
Abnormal & $32(51.6 \%)$ \\
\hline Total & $62(100 \%)$ \\
\hline
\end{tabular}

Data in Table 1 showed that consumption of iron table supplement by pregnant women in Johan Pahlawan Subdistrict of West Aceh could be categorized into two groups namely pregnant women had sufficient supplement of Fe tablet and those had insufficient intake of iron tablet. Data in the Table 1 shows that $41.9 \%$ $(26 / 62)$ of pregnant women in the study area consumed sufficient Fe supplement and the rest 58.1\% (36/62) consumed insufficient Fe supplements. This situation was assummed caused by infsufficinet knowledge of people in the region about the benefits of iron tablets consumtion for both omother and pregnant women.

The proportion of pregnant women had enough $\mathrm{Fe}$ tablet consumption in Johan Pahlawan District was lower than the regencial and provincial coverage rates that reached $66 \%$ and $72 \%$, respectively. This figure is even far from the national target of Fe-tablet coverage that must be above $90 \%[13,14]$. A lower $(8.6 \%)$ proportion of pregnant women with sufficient $\mathrm{Fe}$ tablet consumption was reported by Puspitaningrum dan Fratika [18]. A study performed by Rizki et al. [16], on the other hand, found a slightly higher number $(57.6 \%)$ of pregnant women consume enough Fe tablet supplement.

\subsection{Hemoglobin Levels of Pregnant Women}

This study found that $\mathrm{Hb}$ level of pregnant women in Johan Pahlawan could be categorized to normal or abnormal (Table 1). Proportion of pregnant women with normal $\mathrm{Hb}$ level (48.8\%) is lower that those with abnormal $\mathrm{Hb}$ level (51.6\%). This high prevalence of anemic pregnant women (the latter) might result in increased morbidity and mortality, both for the mother herself and the child born [19]. Anemia in pregnancy can decrease in the quality of human resources in general from delayed growth of body and brain cells [14].

This study is in line with research conducted by Wiraprasidi et al. [20] where pregnant women who suffer from anemia with abnormal hemoglobin levels were found to be $94.1 \%$. Previous research conducted by Sugiarsih and Wariyah (21) also found that pregnant women suffering from anemia with abnormal hemoglobin levels were 54.6\%. According to the assumptions of researchers in Johan Pahlawan sub-district, West Aceh district, more pregnant women suffer from anemia with abnormal hemoglobin levels because most pregnant women do not consume enough iron $(\mathrm{Fe})$ tablets and lack of foods containing high protein and nutrients.

\subsection{Iron Supplement Adequacy and Hemoglobin Level of Pregnant Women}

The proportion of pregnant women who consumed enough Fe tablet with normal $\mathrm{Hb}$ level was $80.8 \%$, higher than pregnant women who consume insufficient Fe tablet with normal Hb level (25\%). The proportion of pregnant women who consumed insufficient Fe tablet with abnormal $\mathrm{Hb}$ level (75\%) was higher than those consumed enough Fe tablet with normal Hb level (19.2\%) (Table 2). 
Table 2. The adequacy of Fe supplement and $\mathrm{Hb}$ level of pregnant women in Johan Pahlawan, West Aceh

\begin{tabular}{|c|c|c|c|c|c|c|c|c|}
\hline \multirow{3}{*}{ Iron Tablet } & \multicolumn{6}{|c|}{ Hemoglobin levels } & \multirow{3}{*}{ OR } & \multirow{3}{*}{ P value } \\
\hline & \multicolumn{2}{|l|}{ Normal } & \multicolumn{2}{|c|}{ Abnormal } & \multicolumn{2}{|l|}{ Total } & & \\
\hline & Number & $\%$ & Number & $\%$ & Number & $\%$ & & \\
\hline Not Enough & 9 & 25 & 27 & 75 & 36 & 100 & 12.60 & 0.000 \\
\hline Enough & 21 & 80.8 & 5 & 19.2 & 26 & 100 & & \\
\hline
\end{tabular}

The OR value is 12.60 , meaning that pregnant women who consume insufficient $\mathrm{Fe}$ tablet are 12 times more likely to have abnormal $\mathrm{Hb}$ level than those consume enough $\mathrm{Fe}$ tablet. Iron adequay is a risk factor for abnormal $\mathrm{Hb}$ level in pregnant women in Johan Pahlawan as shown by a significant relationship $(\mathrm{p}<0.01)$ between Fe tablet consumption and their Hb level.

The results of this study are in agreement with the results of previous studies conducted by Rizki et al [16], Ratih [15] and Habib et al. [22] suggesting that Fe tablet supplementation very significantly infuences $\mathrm{Hb}$ level of pregnant women $(\mathrm{p}<0.01)$. Taking Fe supplement every day during pregnancy prevent anemia because more $\mathrm{Fe}$ is required for the increased formation of red blood cells (erythropoiesis) during pregnancy [23].

The need for $\mathrm{Fe}$ in pregnant women increases especially during the $2^{\text {nd }}$ and $3^{\text {rd }}$ trimesters due to increased blood volume and plasma volume during pregnancy. Daily absorption of this mineral from diet is usually not sufficient to fulfill this need. Therefore it is necessary to increase iron intake through iron supplementation to help restore $\mathrm{Hb}$ levels in pregnant women [5]. Daily Fe supplementation is a relatively safe and effective approach to maintaining $\mathrm{Hb}$ concentration and avoiding anemia in pregnancy $[24,25]$.

\section{CONCLUSION}

There is a close relationship between the adequacy of iron (Fe) supplementation and hemoglobin level of pregnant women in Johan Pahlawan District, West Aceh Regency.

\section{AUTHORS' CONTRIBUTION}

All authors equally contributed to the preparation and editing of the manuscript.

\section{ACKNOWLEDGMENT}

The authors would like to acknowledge of the Health Office of West Aceh, the Primary Health Care of Johan Pahlawan, the Primary Health Care of Suak Ribee, and all respondents for their great help and cooperation during the field work.

\section{REFERENCES}

[1] L. Karaoglu, E. Pehlivan, M. Egri, C. Deprem, G. Gunes, M. F. Genc, I. Temel, The prevalence of nutritional anemia in pregnancy in an East Anatolian Province, Turkey, BMC Publ. Health. 10(329) (2010) 1-12.

[2] World Health Organization, Haemoglobin concentrations for the diagnosis of anaemia and assessment of severity, Department of Nutrition for Health and Development, Geneva, 2011.

[3] Ministry of Health Republic of Indonesian (Kementerian Kesehatan RI), Tentang pelayanan kesehatan masa sebelum hamil, masa hamil, persalinan, dan masa sesudah melahirkan, penyelenggaraan pelayanan kontrasepsi serta pelayanan kesehatan seksual. Permenkes nomor 97, 2014.

[4] Aritonang, Kebutuhan Gizi Ibu Hamil, IPB Press, Bogor, 2010.

[5] M.M.V. Seu, J.C. Mose, R. Panigoro, E. Sahiratmadja, Anemia prevalence after iron supplementation among pregnant women in midwifes practice of primary health care facilities in eastern Indonesia, Anemia (2019) 1-8.

[6] S, Prawirohardjo, Ilmu Kebidanan, Edisi ke 4, PT Bina Pustaka, Yogyakarta, 2014.

[7] N.A. Alwan, D.C. Greenwood, N.A.B. Simpson, H. J. McArdle, K.M. Godfrey, J.E. Cade, Dietary iron intake during early pregnancy and birth outcomes in British in a cohort of British women, Human Reprod. 26(4) (2011) 911-919.

[8] Ministry of Health Republic of Indonesian (Kementerian Kesehatan RI), Riset Kesehatan Dasar, Jakarta, Badan Pusat Penelitian dan Pengembangan Kesehatan (Puslitbangkes), 2013.

[9] Ministry of Health Republic of Indonesian (Kementerian Kesehatan RI), Riset Kesehatan Dasar, Jakarta, Badan Pusat Penelitian dan Pengembangan Kesehatan (Puslitbangkes), Jakarta, 2018. 
[10] West Aceh District Health Office., Profil Kesehatan Aceh Barat tahun 2019, Aceh Barat, 2019.

[11] West Aceh District Health Office, Profil Kesehatan Aceh Barat tahun 2018, Aceh Barat, 2018.

[12] Aceh Health Office, Profil Kesehatan Aceh, Aceh, 2018.

[13] Ministry of Health Republic of Indonesia (Kementerian Kesehatan RI), Peraturan Menteri Kesehatan Republik Indonesia Nomor 75. Tentang Angka Kecukupan Gizi yang Dianjurkan Bagi Bangsa Indonesia, 2013.

[14] Ministry of Health Republic of Indonesia (Kementerian Kesehatan RI), Buku Kesehatan Ibu dan Anak, Jakarta, Direktorat Jenderal Bina Kesehatan Masyarakat, 2016.

[15] R.H. Ratih, Pengaruh pemberian tablet zat besi (Fe) terhadap peningkatan kadar hemoglobin pada ibu hamil yang anemia. Jomis (J. Midwifery Sci.) 1(1) (2017) 30-34.

[16] F. Rizki, N.I. Lipoeto, H. Ali, Hubungan suplementasi tablet Fe dengan kadar hemoglobin pada ibu hamil trimester III di Puskesmas Air Dingin kota Padang. Jurnal Kesehatan Andalas 6(3) (2017) 502-506.

[17] S. Notoatmodjo, Metodologi Penelitian Kesehatan, Rineka Cipta, Jakarta, 2010.

[18] D. Puspitaningrum, N.M. Fratika, Hubungan pengetahuan tentang anemia, pendidikan ibu, konsumsi tablet $\mathrm{Fe}$ dengan kadar $\mathrm{Hb}$ pada ibu hamil trimester III di RB Bhakti Ibu Kota Semarang, Universitas Muhammadiyah Semarang, Semarang, 2014.
[19] E. Oliver, K Olufunto, Management of anaemia in pregnancy, In Anemia, D. Silverberg (Ed.), Intechopen, 2012.

[20] I P. Wiraprasidi, S.E. Kawengian, N. Mayulu, Faktor-faktor yang berhubungan dengan kadar hemoglobin pada ibu hamil di Puskesmas Lolak. eBiomedic. 5(2) (2017) 1-13.

[21] U. Sugiarsih, Wariyah, Hubungan tingkat sosial ekonomi dengan kadar hemoglobin. Jurnal Kesehatan Reproduksi. 4(2) (2013) 86-92.

[22] M.A. Habib, C.R. Greenow, S.B. Soofi, N. Ali, S. Nausheen, I. Ahmed, Z.A. Bhutta, K.I. Black, Prevalence and determinants of iron deficiency among non-pregnant women of reproductive age in Pakistan. Asia Pac. J. Clin. Nutr. 27(1) (2018) 195203.

[23] H.A. Chowdhury, K.R. Ahmed, F. Jebunessa, J. Akter, S. Hossain, M. Shahjahan, Factors associated with maternal anaemia among pregnant women in Dhaka City, BMC Womens Health. 15(77) (2015) 16.

[24] H. Shankar, N. Kumar, R. Sandhir, S. Mittal, S. Kurra, L. Dhaliwal, G. Kaur, N. Chandhiok, B. S. Dhillon, D. N. Rao, Weekly iron folic acid supplementation plays differential role in maintaining iron markers level in non-anaemic and anaemic primigravida: A randomized controlled study. Saudi J. Biol. Sci. 23 (2016) 724-730.

[25] Almatsier S., Prinsip Dasar Ilmu Gizi. Jakarta: Penerbit PT Gramedia Pustaka Utama, 2009. 